\title{
Ultrasonic Activation of Suzuki and Hiyama Cross-Coupling Reactions Catalyzed by Palladium
}

\author{
Khemais Said*, Ridha Ben Salem \\ Physical Organic Chemistry Laboratory (UR11ES74), Science Faculty of Sfax, University of Sfax, Sfax, Tunisia \\ Email: "saidkhemais1@gmail.com, Ridha.BenSalem@yahoo.fr
}

Received 12 January 2016; accepted 11 April 2016; published 14 April 2016

Copyright (C) 2016 by authors and Scientific Research Publishing Inc.

This work is licensed under the Creative Commons Attribution International License (CC BY). http://creativecommons.org/licenses/by/4.0/

(c) (i) Open Access

\section{Abstract}

The coupling reaction of aryl bromide and aryl boronic acid in water/DMF as solvent was studied using a palladium-complex as a catalyst in the presence of ultrasound at room temperature. The effect on the reaction of a base and a solvent was also studied with and without ultrasound and was found to increase the speed of the reaction. In this regard, we propose reaction mechanisms that could explain the results obtained.

\section{Keywords}

\section{Palladium, Suzuki Cross-Coupling, Hiyama, Ultrasound, Sonochemical Activation}

\section{Introduction}

Due to the urgent need for solutions to the increasing environmental problem of pollution, awareness has recently grown to limit all its sources as much as possible. Hence, chemists have sought to change the conventional methods of organic synthesis so as to make them more efficient and environmentally friendly. This lies within the framework of a new vision of chemistry known as "green chemistry". To do so, new synthesis strategies and activation methods are established to adhere to regulations around the world. Among the eco-compatible activation methods we can mention temperature, light, pressure, ultrasound and microwave as physical activation methods, phase transfer catalysis as a chemical activation method, and enzymatic catalysis as a biochemical activation method. These new unconventional methodologies involve green chemistry, which is a developing discipline involving selective high-yield catalysis, solvent-free syntheses that are economical in terms of energy and raw material, clean processes and biodegradable materials.

\footnotetext{
${ }^{*}$ Corresponding author.
} 
This research work is interested in studying bi-activation through ultrasonic bias [1]-[10] coupled with the phase transfer catalysis [11]-[16] of some organic reactions. Thus, we propose to investigate the effects of ultrasonic wave cavitation (mono activation) combined with the effects of phase transfer catalysis on the performance of Suzuki [17]-[24] and Hiyama [25]-[35] reactions.

\section{Materials and Methods}

All compounds were characterized by IR, ${ }^{1} \mathrm{H}$ NMR spectra, ${ }^{13} \mathrm{C}$ NMR spectra and mass spectra. The IR spectra were recorded in $\mathrm{KBr}$ with a JASCO FT-IR-420 spectrometer, with a precision of $\pm 2 \mathrm{~cm}^{-1}$ in the $400-4000$ $\mathrm{cm}^{-1}$ range. The ${ }^{1} \mathrm{H}$ NMR spectra (400 MHz) and ${ }^{13} \mathrm{C}$ NMR spectra (100 MHz) were obtained on a Bruker AC300 spectrometer using $\mathrm{CDCl}_{3}$ as solvent and TMS as an internal standard. Chemical shift is given in ppm.

The coupling products were analyzed by GC-MS (Hewlett-Packard computerized system consisting of a 5890 gas chromatograph coupled with a 5971A mass spectrometer) using fused-silica-capillary columns with a polar stationary phase: Supelcowax 10 (60 m $\times 0.2 \mathrm{~mm} \times 0.20 \varnothing$ film thickness). GC-MS analyses were obtained using the following conditions: carrier gas He; flow rate $1 \mathrm{ml} / \mathrm{min}$; split 1:20; injection volume 0.1 ll; injection temperature $250^{\circ} \mathrm{C}$; oven temperature programmed from 60 to $220^{\circ} \mathrm{C}$ at $4^{\circ} \mathrm{C} / \mathrm{min}$ and holding at $220^{\circ} \mathrm{C}$ for 30 min; ionization mode used was electronic impact at $70 \mathrm{eV}$.

PL spectra were measured on a $\mathrm{C}_{6} \mathrm{PbI}_{4}$ thin film using a double monochromator U1000 equipped with a photomultiplier. The excitation wavelength was the $325 \mathrm{~nm}(3.815 \mathrm{eV})$ line of a Spectra-Physics beamlock 2085 Argon laser.

Melting points were taken on a Reichert-Heizbank apparatus.

\section{Results and Discussion}

In the present research work, the study of some Suzuki and Hiyama coupling reactions using arylboronic acids (2a), trimethoxy(Aryl)silane (4a-4b) and aryl bromides (1a) [36] [37] is described. The catalytic system used is chloride Bis (acetonitrile) dichloropalladium (II)/triphenylphosphine $\left(\mathrm{PdCl}_{2}(\mathrm{MeCN})_{2} / \mathrm{PPh}_{3}\right)$ in a basic environment and in the presence of a solvent. The coupling product is formed either under ultrasonic irradiation or by magnetic stirring.

\subsection{Effects of Solvents on the Suzuki Reaction between 1a and 2a}

As was found in [5], at a constant temperature and pressure, any reaction has a well-defined activation energy. Thus, in order to change this reaction, a specific activation must be introduced into the reaction system. Such specific activation is intended to decrease $\Delta G^{\#}$ or provide enough energy for the system to access the transition state surmounting the potential barrier. Within the framework of this hypothesis, the 1a and 2a were allowed to react in the presence of a palladium catalyst in various solvents. The influence of the polarity of the solvent on the yield of this reaction is illustrated in Table 1.

As can be seen in Table 1, the solvents used are those most commonly found in the literature. Indeed, Suzuki coupling requires slight or moderate polar solvents, the nature of which is decisive for the yield. However, the yields tend to decrease when moving from a polar to a nonpolar solvent. A higher dielectric constant is associated with better performance. The separating power of the solvent is directly related to the dielectric constant and has the effect of accelerating the coupling process. Thus, through the dissociation of basic cation-anion binding, the use of a solvent with a high dielectric constant leads to significant activation of the basic unit. In the alcohol solvents the yields are above $40 \%$. The Suzuki reaction, however, seems to be slightly slower in the case of toluene (8\%) than in that of methanol (47\%). In the presence of a water/DMF mixture, a very good selectivity is obtained in both cases ( $58 \%$ and $52 \%$ in $\mathrm{v} / \mathrm{v}=1: 1 \mathrm{v} / \mathrm{v}=1: 2$, respectively). The mixture of two water-formaldehyde solvents is generally considered as the best solvent for this reaction. These solvents are likely to interact with the 2a by complexation, i.e. the oxygenated compounds have a high affinity for boron derivatives, thus facilitating the transmetalation step.

\subsection{Effect of Basic Catalysts on the Suzuki Cross-Coupling Reaction}

The aim of studying the impact of the base nature on the evolution of the Suzuki reaction between $2 \mathbf{a}$ and $1 \mathrm{a}$ in 
Table 1. The results of the Suzuki coupling reaction between 1a and $2 \mathbf{a}$ in various solvents.

\begin{tabular}{|c|c|c|c|c|}
\hline Entry & Solvent & $\varepsilon$ à $25^{\circ} \mathrm{C}$ & Yield (\%)a* & Yield (\%)b \\
\hline 1 & $\mathrm{MeOH}$ & 33 & 47 & 88 \\
\hline 2 & $\mathrm{EtOH}$ & 32.6 & 43 & 81 \\
\hline 3 & iPrOH & 18 & 40 & 79 \\
\hline 4 & THF & 7.58 & 22 & 50 \\
\hline 5 & Toluene & 2.38 & 8 & 40 \\
\hline 6 & Acetonitrile & 37.5 & 35 & 72 \\
\hline 7 & DMF & 36.70 & 27 & 40 \\
\hline 8 & Water & 87 & 34 & 77 \\
\hline 9 & Water/Acetonitrile $(\mathrm{v} / \mathrm{v}=1: 1)$ & - & 15 & 20 \\
\hline 10 & Water/EtOH (v/v = 1:1) & - & 55 & 90 \\
\hline 11 & Water/DMF $(\mathrm{v} / \mathrm{v}=1: 1)$ & - & 58 & 95 \\
\hline 12 & Water $/ \mathrm{MeOH}(\mathrm{v} / \mathrm{v}=1: 1)$ & - & 33 & 52 \\
\hline 13 & Water $/ \mathrm{MeOH}(\mathrm{v} / \mathrm{v}=2: 1)$ & - & 54 & 90 \\
\hline 14 & Water/EtOH $(\mathrm{v} / \mathrm{v}=2: 1)$ & - & 59 & 94 \\
\hline 15 & Water/i-PrOH $(\mathrm{v} / \mathrm{v}=2: 1)$ & - & 48 & 85 \\
\hline 16 & Water/Dioxane (v/v = 2:1) & - & 48 & 89 \\
\hline 17 & Water/THF $(\mathrm{v} / \mathrm{v}=2: 1)$ & - & 49 & 73 \\
\hline 18 & Water DMF $(\mathrm{v} / \mathrm{v}=2: 1)$ & - & 52 & 89 \\
\hline
\end{tabular}

${ }^{\mathrm{a}}$ Reaction conditions: $\mathrm{PdCl}_{2}(\mathrm{MeCN})_{2}(0.02 \mathrm{mmol}), \mathbf{1 a}(1.0 \mathrm{mmol}), 2 \mathrm{2a}(1.5 \mathrm{mmol}), \mathrm{K}_{2} \mathrm{CO}_{3}(2 \mathrm{mmol}), \mathrm{PPh}_{3}(0.6 \mathrm{mmol})$ and solvent $(3 \mathrm{~mL})$ at $100^{\circ} \mathrm{C}$ for $8 \mathrm{~h} ;{ }^{\mathrm{b}} \mathrm{PdCl}_{2}(\mathrm{MeCN})_{2}(0.02 \mathrm{mmol}), \mathbf{1 a}(1.0 \mathrm{mmol}), 2 \mathrm{a}(1.5 \mathrm{mmol}), \mathrm{K}_{2} \mathrm{CO}_{3}(2 \mathrm{mmol}), \mathrm{PPh}_{3}(0.6 \mathrm{mmol})$ and solvent $(3 \mathrm{~mL})$, Ultrasonic irradiation for 5 min; ${ }^{*}$ Determined by means of GC, based on the 1a, yields in parenthesis are those of purified products.

water/DMF is to provide some additional elements to the process. That's why several trials involving various types of basic catalysts were made.

The analysis of the results in Table 2 reveals that the Suzuki coupling reaction catalyzed by palladium using 1a by magnetic stirring at $100^{\circ} \mathrm{C}$ did not occur in the absence of a base. Therefore, the yield was found to depend on the nature of the base used. This is in line with previous findings [5]. Besides, the various bases studied are of the type: $\mathrm{Et}_{3} \mathrm{~N}, \mathrm{NaOH}, \mathrm{KOH}, \mathrm{Na}_{2} \mathrm{CO}_{3}, \mathrm{~K}_{2} \mathrm{CO}_{3}, \mathrm{Cs}_{2} \mathrm{CO}_{3}, \mathrm{~K}_{3} \mathrm{PO}_{4}$ (Table 2). The reactivity increased with the addition of inorganic bases such as $\mathrm{KOH}, \mathrm{Na}_{2} \mathrm{CO}_{3}, \mathrm{~K}_{2} \mathrm{CO}_{3}$ and $\mathrm{Cs}_{2} \mathrm{CO}_{3}$. It was observed that these carbonate anions were more effective and gave yields exceeding $40 \%$. Nevertheless, the addition of organic bases induces slightly lower yields than those obtained in the presence of inorganic ones. In contrast, the obtained results have shown that the bigger the size of the alkali metal cation associated with the carbonate anion is, the more the biphenyl reactivity increases. In fact, the cation size has a direct impact on the value of the reticular energy of the carbonates considered.

As a result, in the presence of these bases, the free carbonate anion in the environment is insufficiently activated, which leads to the weakening of the base cation-anion attraction force [5]. Thus, the larger the increase of the alkali cation size the more significant the carbonate ion reactivity. The size of the alkali cation also leads to the formation of a more nucleophilic quaternary boronate species allowing for transmetalation. Carbonate-type bases are known to be effective during Suzuki coupling, which, when performed under nitrogen pressure, do not 
Table 2. Influence of the nature of the base on the evolution of the Suzuki reaction involving 1a and 2a.

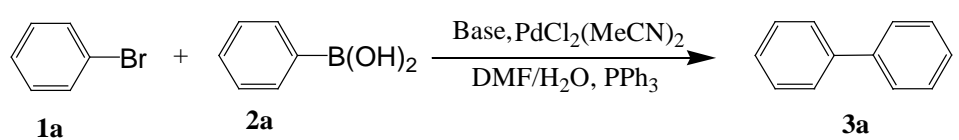

\begin{tabular}{cccc}
\hline Entry & Base & Reticular energy Kj.mol $^{-1}$ & ${\text { Yield }(\%)^{\mathrm{a}^{*}}}$ \\
\hline 1 & - & - & 0 \\
2 & $\mathrm{Et}{ }_{3} \mathrm{~N}$ & - & 40 \\
3 & $\mathrm{KOH}$ & - & 50 \\
4 & $\mathrm{NaOH}$ & 824 & 35 \\
5 & $\mathrm{Na}_{2} \mathrm{CO}_{3}$ & 2301 & 14 \\
6 & $\mathrm{KO}^{t} \mathrm{Bu}$ & - & 58 \\
7 & $\mathrm{Cs}_{2} \mathrm{CO}_{3}$ & 1921 & 53 \\
9 & $\mathrm{~K}_{2} \mathrm{CO}_{3}$ & 2084 & 48 \\
\hline
\end{tabular}

${ }^{\mathrm{a}}$ Reaction conditions: $\mathrm{PdCl}_{2}(\mathrm{MeCN})_{2}(0.02 \mathrm{mmol})$, 1a (1.0 mmol), $2 \mathrm{a}(1.5 \mathrm{mmol})$, base (2 mmol), $\mathrm{PPh}_{3}(0.6 \mathrm{mmol})$, water, $(1.5 \mathrm{~mL}), \mathrm{DMF}(1.5 \mathrm{~mL})$, $100^{\circ} \mathrm{C}, 8 \mathrm{~h}$; ${ }^{*}$ Determined by means of GC, based on the $1 \mathrm{a}$, yields in parenthesis are those of purified products.

alter their efficiency. Indeed, the use of cesium or potassium carbonate provides good conversions with a slight advantage to $\mathrm{Cs}_{2} \mathrm{CO}_{3}$. The opposite-ion, however, does not seem to affect the selectivity for it was found to be perfect and identical in both cases.

\subsection{Effect of Ultrasound on the Suzuki Coupling Reaction}

The present research work undertakes the study of the effect brought by the ultrasounds on the yield of Suzuki reactions involving 1a-1h and $\mathbf{2 a - 2 p}$ in a water /dimethylformamide mixture and using $\mathrm{Cs}_{2} \mathrm{CO}_{3}$ as a base.

The results reported in Table 3 show that the obtained yield is relatively small (of the order of 35\%) in the absence of sonochemical activation although the reaction time is relatively long $(8 \mathrm{~h})$. Nonetheless, the reactivity increases reaching a yield of the order of $84 \%$ in a very remarkable time of 5 minutes in the presence of ultrasonic waves. Indeed, thanks to the physical effects of the cavitation, resulting in the spray of $\mathrm{Cs}_{2} \mathrm{CO}_{3}$ powder, a better contact between the solid-liquid heterogeneous environments is created in the presence of ultrasound in the reaction environment. Furthermore, this phenomenon provides considerable energy to the reaction, and hence the synthesis of 3a-3p with good yields (77\% - 93\%) can be obtained. It is noticed that not only are the yields significantly improved, but also the insulated products under ultrasound have an increased purity. The acceleration of the reaction under ultrasound is probably due to the chemical effects of cavitation which consists in bubbles forming in the liquid and which undergo an implosion after their growth.

These bubbles constitute chemical microreactors in which very high temperature and pressure values in the final stage of their implosion are reached causing the high release of energy. This allows for the stirring of the reaction environment, an activation of the catalytic system and the nearing of reactants by increasing their specific surface area and mixing the liquid layers located near them. This leads to an increase in the contact between the reactants promoting the formation of the product for a very short period of time and with very high yields.

\subsection{The Cross-Coupling Hiyama Reaction between 1a and 4a in the Presence of a Base and a Soluble Catalyst Such as $\mathrm{PdCl}_{2}(\mathrm{MeCN})_{2} / \mathrm{Ph}_{3} \mathrm{P}$}

\subsubsection{Effects Linked to the Solvent}

In order to examine the effect of the solvent type on the course of the Hiyama reaction [38], a reaction of 1a with 4a [35] [39] was performed in the presence of a catalyst in various solvents. The effect of solvent polarity on the yield of this reaction is illustrated in Table 4. 
Table 3. The yields obtained in the presence of ultrasound or in its absence.

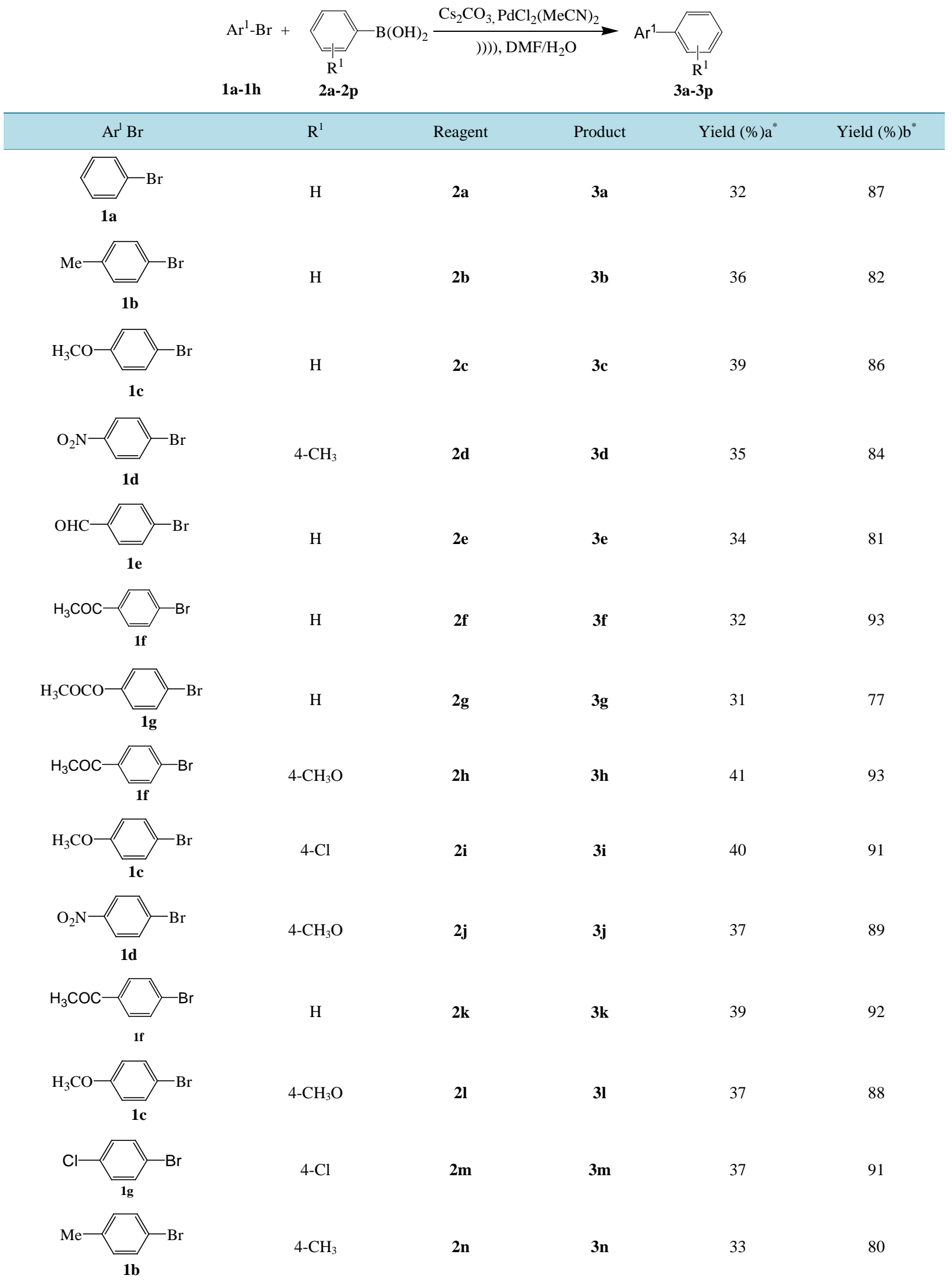




\section{Continued}<smiles>N#Cc1c#cc(Br)cc1</smiles>

$1 h$<smiles>Brc1ccccc1</smiles>

$1 a$
4-CN

4-Cl
20

2p
3 o

3p
35

43
90

91

${ }^{\mathrm{a}}$ Reaction conditions: $\mathrm{PdCl}_{2}(\mathrm{MeCN})_{2}(0.02 \mathrm{mmol}), \mathbf{1 a}-\mathbf{1 h}(1.0 \mathrm{mmol}), \mathbf{2 a - 2 p}(1.5 \mathrm{mmol}), \mathrm{Cs}_{2} \mathrm{CO}_{3}(2 \mathrm{mmol}), \mathrm{PPh}_{3}(0,6 \mathrm{mmol})$, water $(1.5 \mathrm{~mL})$ in $\operatorname{DMF}(1.5 \mathrm{~mL})$ at $100^{\circ} \mathrm{C}$ for $8 \mathrm{~h}$; ${ }^{\mathrm{P}} \mathrm{PdCl}_{2}(\mathrm{MeCN})_{2}(0.02 \mathrm{mmol}), \mathbf{1 a}-\mathbf{1 h}(1.0 \mathrm{mmol}), \mathbf{2 a - 2 p}(1.5 \mathrm{mmol}), \mathrm{Cs}_{2} \mathrm{CO}_{3}(2 \mathrm{mmol}), \mathrm{PPh}_{3}(0.6 \mathrm{mmol})$, water (1.5 $\mathrm{mL}$ ) in DMF (1.5 mL), Ultrasonic irradiation $5 \mathrm{~min}, 25^{\circ} \mathrm{C}$; ${ }^{*}$ Determined by means of GC, based on the $\mathbf{1 a}-\mathbf{1 h}$; yields in parenthesis are those of purified products.

Table 4. Effect of solvent on the reactivity of the Hiyama reaction under ultrasounds irradiation and magnetic stirring.

)))): ultrasound

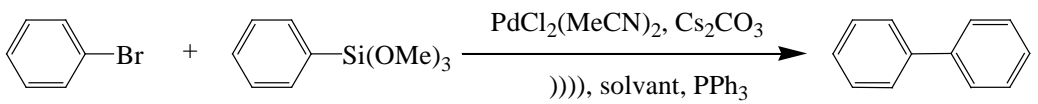

1a

4a

$5 \mathbf{a}$

\begin{tabular}{|c|c|c|c|}
\hline Entry & Solvent & Yield $(\%)^{\mathrm{a}^{*}}$ & Yield $(\%)^{b^{*}}$ \\
\hline 1 & $\mathrm{EtOH}$ & 24 & 51 \\
\hline 2 & $\mathrm{CH}_{3} \mathrm{CN}$ & 31 & 63 \\
\hline 3 & Water & 23 & 45 \\
\hline 4 & DMSO & 15 & 30 \\
\hline 5 & DMF & 25 & 45 \\
\hline 6 & THF & 32 & 50 \\
\hline 7 & toluene & trace & trace \\
\hline 8 & Water/THF $(\mathrm{v} / \mathrm{v}=1: 1)$ & 9 & 39 \\
\hline 9 & Water/EtOH (v/v = 1:1) & 29 & 56 \\
\hline 10 & Water/DMSO (v/v = 1:1) & 40 & 70 \\
\hline 11 & Water/DMF $(v / v=2: 1)$ & 45 & 88 \\
\hline 12 & Water/DMF $(\mathrm{v} / \mathrm{v}=1: 1)$ & 62 & 96 \\
\hline 13 & Water/Acetonitrile $(\mathrm{v} / \mathrm{v}=1: 1)$ & 46 & 76 \\
\hline
\end{tabular}

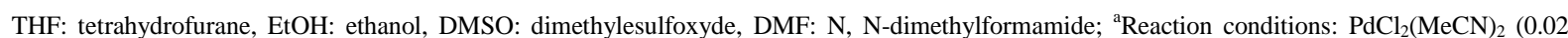
mmol), 1a $(1.0 \mathrm{mmol}), 2 \mathrm{a}(1.5 \mathrm{mmol})$, base $(2 \mathrm{mmol}), \mathrm{PPh}_{3}(0.6 \mathrm{mmol})$, water $(1.5 \mathrm{~mL})$ in DMF $(1.5 \mathrm{~mL}), 100^{\circ} \mathrm{C}, 8 \mathrm{~h}$ bultrasounds for $5 \mathrm{~min}$; ${ }^{*}$ Determined by means of GC, based on the 1a, yields in parenthesis are those of purified products.

Table 4 shows the Hiyama coupling reaction involving 1a and 4a in different solvents at different temperatures.

The impact of the organic co-solvent on the organic solvent system/ $\mathrm{H}_{2} \mathrm{O}(1: 1)$ and the relationship with the solvent mixture $\mathrm{DMF} / \mathrm{H}_{2} \mathrm{O}$ was studied (Table 4). Among the aqueous binary systems, it is worth mentioning that dimethylformamide (DMF) is the most effective co-solvent. Aprotic polar solvents such as acetonitrile $\left(\mathrm{CH}_{3} \mathrm{CN}\right)$, dimethylesulfoxyde (DMSO) and tetrahydrofuran (THF) lead to lower yields (entries 10, 11 and 13). In the presence of an aprotic polar solvent, the coupling yield is not improved (entry 9). A binary system is required for the catalysis as confirmed by the increase in the yield (entries 11, 12). The DMF/ $\mathrm{H}_{2} \mathrm{O}(1: 1)$ mixture (entry 12) is considered the best system in the Hiyama coupling. It is worth noting that the reaction in the aqueous environment does not allow for the best coupling (entry 3); and that when toluene was used no product was detected (entry 7). 
In the light of these results, the assessment of the $\mathbf{5 a}$ coupling was studied using the $\mathrm{DMF} / \mathrm{H}_{2} \mathrm{O}$ solvent system $(1: 1)$.

\subsubsection{Ultrasonic Activation of Hiyama Reactions in the Presence of Aliquat-336}

To illustrate the effect of ultrasound and phase transfer catalysts on the Suzuki reaction trials (Table 5) were carried out involving the coupling of the 1a-1d, $\mathbf{1 f}, \mathbf{1 h}, \mathbf{1} \mathbf{i}-\mathbf{1 k}$ with $\mathbf{4 a}, \mathbf{4 b}$ in a mixture of water and dimethylformamide. The first trial was performed under magnetic stirring, the second one under ultrasonic irradiation and the last one under ultrasonic irradiation in the presence of a phase-transfer catalyst.

When working under standard conditions the yield was found to be relatively low. However, in the presence of ultrasound and/or with Aliquat-336 the reaction was almost complete. The acceleration of the reaction under ultrasound is probably due to the chemical effects of cavitation which consists in the formation of bubbles in the liquid and which undergo an implosion after their growth. These bubbles constitute chemical microreactors in which very high temperatures and pressures are reached in the final stage of their implosion are reached causing a high release of energy. This allows for the stirring of the reaction environment, the activation of the catalytic system and the nearing of reagents by increasing their specific surface area and mixing the liquid layers located near them. The increase in the contact between the reactants can therefore be induced, which promotes the formation of the product in a very short time and with very high yields. The set of phenomena, stirring, pressure, temperature, ionization, etc., generated by ultrasounds leads to the disruption of the classical reaction mechanisms. Hence, very high yields have been observed under ultrasounds in the water-DMF environments and in the presence of phase transfer catalysts.

However, the anionic and sonochemical bi-activation also produces purer products with higher yields, which significantly increase if ultrasound is used with a remarkable decrease in reaction time (8 hours to 5 minutes). This can be explained by the fact that ultrasounds improve the contact of heterogeneous liquid-solid environments through the effects of microemulsion also providing energy to the reaction. Nonetheless, there is not much difference between the yields obtained when using ultrasound and those using both the ultrasound and Aliquat-336. Indeed, given that the reaction is almost complete in the presence of ultrasounds, the phase-transfer catalyst no longer has a big role to play.

The yield of these reactions significantly improved, reaching $80 \%$, in the simultaneous presence of ultrasound and Aliquat-336 in a record time of 5 minutes. Indeed, as shown in Scheme 1 that displays the reaction mechanism, the ion exchange reaction between $\mathrm{Cs}_{2} \mathrm{CO}_{3}$ and Aliquat-336 induces the formation of an ammonium hydroxide ion which becomes lipophilic, and thus soluble in the organic phase. Furthermore, the $\mathrm{HCO}_{3}^{-}$, ${ }^{+} \mathrm{N}(\mathrm{Oct})_{3} \mathrm{Me}$ ion couple is less associated than the $\mathrm{Cs}^{+}, \mathrm{HCO}_{3}^{-}$ions, which leads to an exaltation of the basicity of the $\mathrm{HCO}_{3}^{-}$ion in the case where the used ion pair is $\mathrm{HCO}_{3}^{-},{ }^{+} \mathrm{N}(\mathrm{Oct})_{3} \mathrm{Me}$. The reactivity order of the hydroxide ions was seen to increase with the increase in the cation size.

To further evidence these results, we propose the most likely reaction mechanism for this Hiyama coupling reaction in the two-phase water/dimethylformamide environment in the presence of TCP (Scheme 1).

\subsection{PL Properties of Pd Aliquat-336}

Scheme 2 illustrates the photoluminescence spectrum of Pd Aliquat-336. The PL spectra of the prepared samples are obtained as a result of the competition among electron-hole separations, electron-phonon scattering and electron-hole recombination. Two emissions are observed in the PL spectra, the first one is a weak blue emission located at about $420 \mathrm{~nm}$ and is attributed to the carbon chain, which is due to trap the state emission based on the large Stokes shift from the band gap energy. The second emission at $470 \mathrm{~nm}$ may be due to the recombination between the shallow donor level (S vacancy) and the $\mathrm{t}_{2}$ level of the $\mathrm{Pd}^{2+}$ ion.

\section{Experimental}

\subsection{Classical Procedure without Ultrasound}

The 1a (1.0 mmol), 2a (1.5 mmol), $\mathrm{Cs}_{2} \mathrm{CO}_{3}(2 \mathrm{mmol})$ and the catalyst $\mathrm{PdCl}_{2}\left(\mathrm{MeCN}_{2}\right)(0.02 \mathrm{mmol}), \mathrm{PPh}_{3}(0.6$ mmol) were placed in a Schlenk tube. Vacuum was applied for 30 minutes, and then argon was admitted. Water $(1.5 \mathrm{~mL})$ and $\mathrm{N}, \mathrm{N}$-dimethylformamide $(1.5 \mathrm{~mL})$ were added. The reaction was carried out at $100^{\circ} \mathrm{C}$ for $8 \mathrm{~h}$. After reaction, the mixture was cooled and the organic phase was extracted (three times) with diethyl ether. The 
Table 5. Synthesis of biaryl via Hiyama reaction of trimethoxy (Aryl) silane and aryl bromides under ultrasonic irradiation.

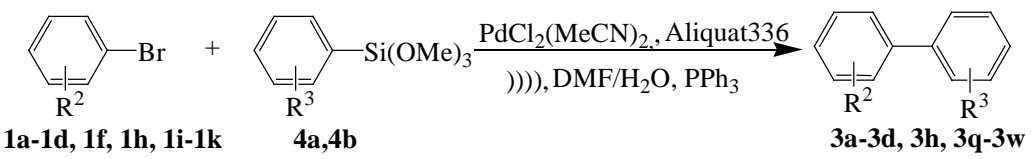

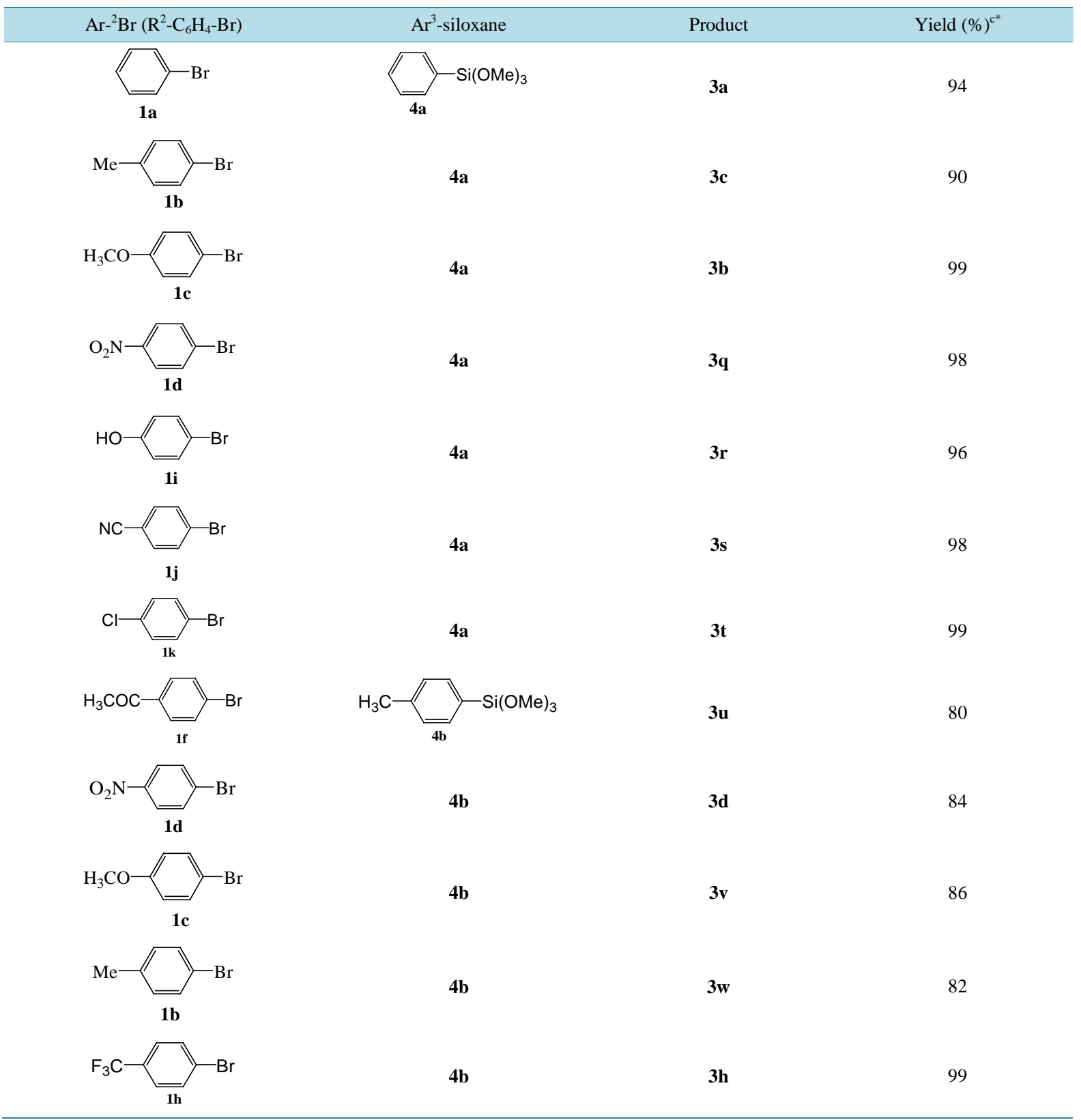

Aliquat-336: N-Methyl-N, N, N-trioctylammonium chloride; ${ }^{\mathrm{c}}$ Reaction conditions: $\mathrm{PdCl}_{2}\left(\mathrm{MeCN}_{2}(0.02 \mathrm{mmol}), \mathbf{1 a - 1 d}, \mathbf{1 f}, \mathbf{1 h}, \mathbf{1 i - 1 k}(1.0 \mathrm{mmol}), \mathbf{4 a}\right.$, $4 \mathbf{b}$ (1.5 mmol), Aliquat-336 (1.25 mmol), $\mathrm{Cs}_{2} \mathrm{CO}_{3}(2 \mathrm{mmol}), \mathrm{PPh}_{3}(0.6 \mathrm{mmol}), \mathrm{DMF}(1,5 \mathrm{~mL})$ and water $(1.5 \mathrm{~mL}), \mathrm{Ultrasonic}$ irradiation at $25^{\circ} \mathrm{C}$ for 5 min. * determined after purification by chromatography.

latter was dried on $\mathrm{MgSO}_{4}$ and the solvent removed under vacuum. The coupling product was finally isolated by silica gel chromatography.

Ultrasonic Irradiation

The ultrasonic probe was immersed directly in the reactor. An ultrasonic generator (sonics VC 505300 W) 


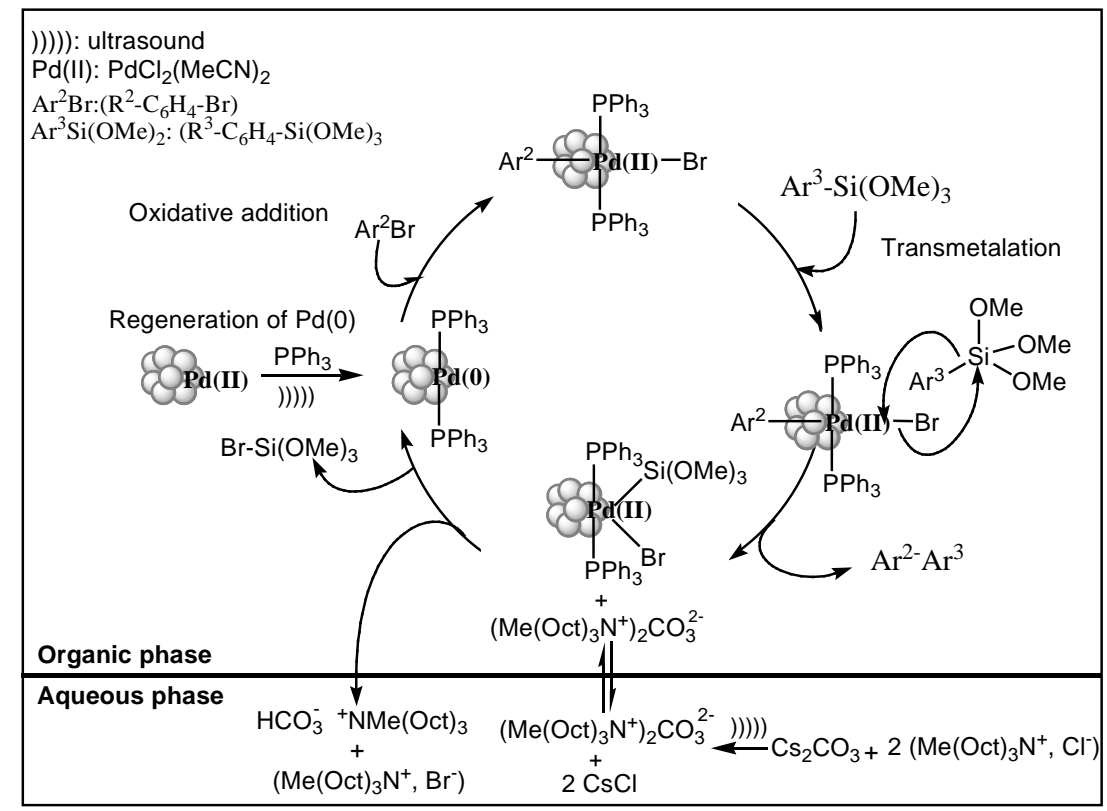

Scheme 1. Proposed mechanism for the Hiyama coupling in the water/DMF biphasic system in the presence of Aliquat-336.

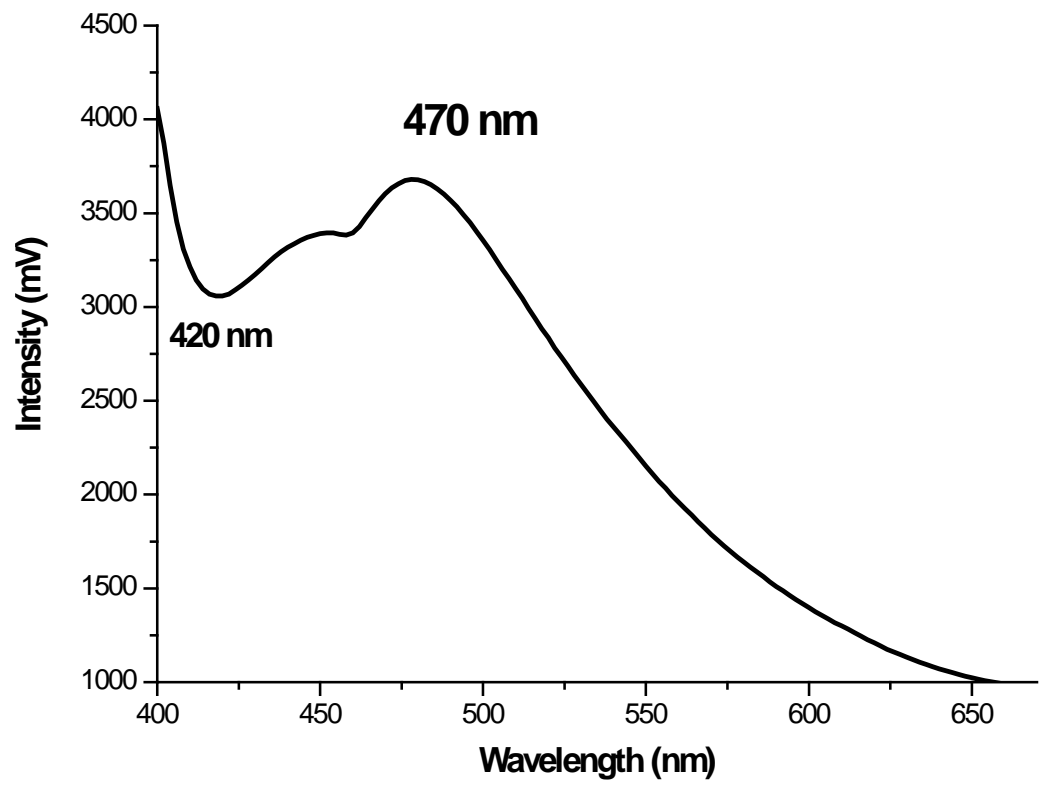

Scheme 2. PL emission spectrum of Pd Aliquat-336 prepared in a mixture of water and DMF.

emits the sound vibration into the reaction mixture. Sonification was achieved at low frequencies of $20 \mathrm{kHz}$ (amplitude of 50\%) at room temperature for $5 \mathrm{~min}$. The 1a (1.0 mmol), Aliquat-336 (1.25 mmol), 2a (1.5 mmol), $\mathrm{Cs}_{2} \mathrm{CO}_{3}, \mathrm{PPh}_{3}(0.6 \mathrm{mmol})$ and the catalyst $\left.\mathrm{PdCl}_{2}(\mathrm{MeCN})_{2}\right)(0.02 \mathrm{mmol})$ are placed in a reactor. Water $(1.5 \mathrm{~mL})$ and $\mathrm{N}, \mathrm{N}$-dimethylformamide $(1.5 \mathrm{~mL})$ are added. After reaction, the mixture is extracted (three times) with diethyl ether. The latter is dried on $\mathrm{MgSO}_{4}$ and the solvent removed under vaccum. The coupling product is finally isolated by silica gel chromatography.

The yields of the reactions were determined by gas chromatography on a Shimadzu 2014-GC apparatus. The capillary column was DB-5 and the carrier gas was helium. 


\subsection{Hiyama Couplings}

\section{General Procedure for the Syntheses of Biaryl}

$\operatorname{PdCl}_{2}(\mathrm{MeCN})_{2}(0.02 \mathrm{mmol})$ was added to a solution of $\mathbf{1 a}(1.0 \mathrm{mmol}), \mathbf{4 a}-\mathbf{4 b}(1.5 \mathrm{mmol})$, Aliquat-336 (1.25 $\mathrm{mmol}), \mathrm{PPh}_{3}(0.6 \mathrm{mmol})$ in a mixture of dimethylformamide $(1.5 \mathrm{~mL})$ and water $(1.5 \mathrm{~mL})$. The reaction mixture was heated to reflux for $8 \mathrm{~h}$. After the reaction, the mixture was cooled and the organic phase was extracted (three times) with water/hexane (1:1). The latter was dried on $\mathrm{MgSO}_{4}$ and the solvent removed under vacuum. The coupling product was finally isolated by silica gel chromatography.

Biphenyl (3a, $\left.\mathrm{C}_{12} \mathrm{H}_{10}\right)$

White solid; m.p.: $66^{\circ} \mathrm{C}-68^{\circ} \mathrm{C} ;{ }^{1} \mathrm{H}$ NMR $\left(\mathrm{CDCl}_{3}\right): \delta=7.63$ - $7.62(\mathrm{~m}, 4 \mathrm{H}), 7.50$ - 7.45 (m, 4H), 7.4 - 7.35 (m, 2H) ppm; ${ }^{13} \mathrm{C}$ NMR $\left(\mathrm{CDCl}_{3}\right): \delta=127.23,127.31,128.81,141.32$ ppm; IR (KBr): $\bar{v}=3032,1946,1568,1475$, 1427, 902, 729, $694 \mathrm{~cm}^{-1}$; MS: $\mathrm{m} / \mathrm{z}(\%)=154\left(\mathrm{M}^{+}, 100\right), 153$ (42), 149 (74), 85 (40), 71 (50).

4-Methylbiphenyl (3b, $\mathrm{C}_{13} \mathrm{H}_{12}$ )

m.p.: $47^{\circ} \mathrm{C}-48^{\circ} \mathrm{C} ;{ }^{1} \mathrm{H}$ NMR $\left(\mathrm{CDCl}_{3}\right): \delta=7.51(\mathrm{~d}, 2 \mathrm{H}, \mathrm{J}=8 \mathrm{~Hz}), 7.44(\mathrm{t}, 2 \mathrm{H}, \mathrm{J}=7 \mathrm{~Hz}), 7.34(\mathrm{t}, 1 \mathrm{H}, \mathrm{J}=7 \mathrm{~Hz})$,

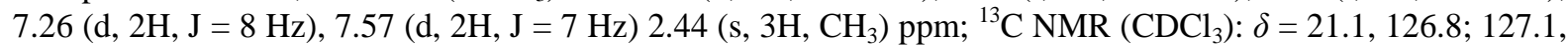
128.6, 129.4, 137.1, 138.3, $141.1 \mathrm{ppm}$.

4-Methoxybiphenyl (3c; $\left.\mathrm{C}_{13} \mathrm{H}_{12} \mathrm{O}\right)$

Colorless solid; m.p.: $85^{\circ} \mathrm{C}-86^{\circ} \mathrm{C} ;{ }^{1} \mathrm{H}$ NMR $\left(\mathrm{CDCl}_{3}\right): \delta=3.85$ (s, 3H), 6.97 (d, 2H, J = $9 \mathrm{~Hz}$ ), 7.28 - 7.35 (m, 1H), 7.41 - 7.46 (m, 2H), 7.52 - $7.58(\mathrm{~m}, 4 \mathrm{H}) \mathrm{ppm} ;{ }^{13} \mathrm{C}$ NMR $\left(\mathrm{CDCl}_{3}\right): \delta=159.4,141.5,134.1,129.0,128.3$, 127.0, 126.7, 114.4, 55.6 ppm; MS: m/z (\%) = $184\left(\mathrm{M}^{+}, 92.5\right), 169$ (77.5), 150 (45.0), 141 (70), 139 (40), 131 (30), 115 (55), 99 (32.5), 91 (52.5), 76 (100), 63 (55.0), 50 (42.5).

4-Nitrobiphenyl (3d, $\mathrm{C}_{12} \mathrm{H}_{9} \mathrm{NO}_{2}$ )

Pale yellow powder; m.p.: $115^{\circ} \mathrm{C}-116^{\circ} \mathrm{C} ;{ }^{1} \mathrm{H}$ NMR $\left(\mathrm{CDCl}_{3}\right): \delta=7.45-7.53(\mathrm{~m}, 3 \mathrm{H}), 7.63-7.66(\mathrm{~m}, 2 \mathrm{H})$, $7.77(\mathrm{~d}, 2 \mathrm{H}, \mathrm{J}=6.9 \mathrm{~Hz}), 8.33(\mathrm{~d}, 2 \mathrm{H}, \mathrm{J}=6.9 \mathrm{~Hz}) \mathrm{ppm} ;{ }^{13} \mathrm{C} \mathrm{NMR}\left(\mathrm{CDCl}_{3}\right): \delta=145.8,139.4,132.7,129.3,128.7$, 128.0, 127.5, 119.1; 111.1 ppm; MS: m/z (\%) = 199 (M+ 35.6), 169 (28.9), 153 (19.3), 152 (100), 127 (20.7), 102 (13.3), 76 (49.6), 50 (40).

4-Biphenylcarbaldehyde (3e, $\left.\mathrm{C}_{13} \mathrm{H}_{10} \mathrm{O}\right)$

mp.: $58^{\circ} \mathrm{C}-60^{\circ} \mathrm{C} ;{ }^{1} \mathrm{H}$ NMR $\left(\mathrm{CDCl}_{3}\right): \delta=10.05(\mathrm{~s}, 1 \mathrm{H}), 7.98-7.96(\mathrm{~m}, 2 \mathrm{H}), 7.78-7.75(\mathrm{~m}, 2 \mathrm{H}), 7.68-7.64$ (m, 2H), $7.52-7.49$ (m, 2H), $7.47-7.44\left(\mathrm{tt}, 1 \mathrm{H}, \mathrm{J}=7.2\right.$, J = 1.2 Hz) ppm; ${ }^{13} \mathrm{C}$ NMR $\left(\mathrm{CDCl}_{3}\right): \delta=192.1,147.4$, 140.0, 135.5, 130.5, 129.2, 128.7, 127.9, 127.6 ppm; IR (KBr): $\bar{v}=3059$, 3032, 2924, 2828, 2735, 1700, 1604, 1565, 1515, 1485, 1450, 1412, 1384, 1308, 1281, 1214, 1170, 1076, 1007, 917, 838, 762, 729, 697, 646, 629, $547 \mathrm{~cm}^{-1}$; MS: m/z (\%) = $183\left(\mathrm{M}^{+}, 18\right), 182\left(\mathrm{M}^{+}, 59\right), 181$ (65), 180 (53), 153 (51), 152 (100), 150 (26), 77 (13), 76 (36).

4-Acetylbiphenyl (3f, $\mathrm{C}_{14} \mathrm{H}_{12} \mathrm{O}$ )

Colorless crystals; m.p.: $117^{\circ} \mathrm{C}-119^{\circ} \mathrm{C} ;{ }^{1} \mathrm{H}$ NMR $\left(\mathrm{CDCl}_{3}\right): \delta=8.03(\mathrm{~d}, 2 \mathrm{H}, \mathrm{J}=8.4 \mathrm{~Hz}), 7.74(\mathrm{~d}, 2 \mathrm{H} \mathrm{J}=8.4$ $\mathrm{Hz}), 7.62$ - 7.64 (m, 2H), $7.34-7.49$ (m, 3H), 2.64 (s, 3H) ppm; ${ }^{13} \mathrm{C}$ NMR $\left(\mathrm{CDCl}_{3}\right): \delta=197.8,146.0,140.4$, 136.4, 129.2, 129.1, 128.5, 127.3, 127.3, 26.8 ppm; MS: m/z (\%) = $196\left(\mathrm{M}^{+}\right), 181,152,76,43$.

4-Acetoxybiphenyl (3g, $\left.\mathrm{C}_{14} \mathrm{H}_{12} \mathrm{O}_{2}\right)$

Pale yellow solid; m.p.: $114^{\circ} \mathrm{C}-116^{\circ} \mathrm{C} ;{ }^{1} \mathrm{H}$ NMR $\left(\mathrm{CDCl}_{3}\right): \delta=8.07-8.03(\mathrm{dt}, \mathrm{J}=8.4, \mathrm{~J}=2 \mathrm{~Hz}, 2 \mathrm{H}), 7.72-$ 7.69 (dt, J = 8.4, J = 1.6 Hz, 2H), $7.67-7.63(\mathrm{~m}, 2 \mathrm{H}), 7.51-7.48(\mathrm{~m}, 2 \mathrm{H}), 7.45-7.41$ (tt, J = 7.6, J = 1.2 Hz, 1H), 2.67 (s, 3H) ppm; IR (KBr): $\bar{v}=2925,2855,1679,1602,1484,1361,1265,1181,1083,960,838,765,722$, $680 \mathrm{~cm}^{-1}$; MS: m/z (\%) = $196\left(\mathrm{M}^{+}, 8\right), 184$ (10), 167 (36), 149 (100), 83 (82), 77 (20).

4-Acetyl-4'-methoxybiphenyl $\left(3 \mathbf{h}, \mathrm{C}_{15} \mathrm{H}_{14} \mathrm{O}\right)$

White crystals; m.p.: $153^{\circ} \mathrm{C}-154^{\circ} \mathrm{C} ;{ }^{1} \mathrm{H}$ NMR $\left(\mathrm{CDCl}_{3}\right): \delta=7.64(\mathrm{~d}, \mathrm{~J}=8.4 \mathrm{~Hz}, 2 \mathrm{H}), 7.54(\mathrm{~d}, \mathrm{~J}=8.7 \mathrm{~Hz}, 2 \mathrm{H})$, $7.02(\mathrm{~d}, \mathrm{~J}=8.7 \mathrm{~Hz}, 2 \mathrm{H}), 8.01(\mathrm{~d}, \mathrm{~J}=8.4 \mathrm{~Hz}, 2 \mathrm{H}), 3.89(\mathrm{~s}, 3 \mathrm{H}), 2.62(\mathrm{~s}, 3 \mathrm{H}) \mathrm{ppm} ; \mathrm{MS}: \mathrm{m} / \mathrm{z}(\%)=226\left(\mathrm{M}^{+}, 44\right)$, 211 (100), 183 (30.5), 168 (28), 152 (33.5), 139 (65.5), 89 (21.6), 77 (20), 63 (40.9), 55 (27.2).

4-Chloro-4'-methoxybiphenyl (3i, $\left.\mathrm{C}_{13} \mathrm{H}_{11} \mathrm{ClO}\right)$

White crystals; m.p.: $112^{\circ} \mathrm{C}-114^{\circ} \mathrm{C} ;{ }^{1} \mathrm{H}$ NMR $\left(\mathrm{CDCl}_{3}\right): \delta=7.47-7.51(\mathrm{~m}, 4 \mathrm{H}), 7.37(\mathrm{~d}, \mathrm{~J}=8.4 \mathrm{~Hz}, 2 \mathrm{H}), 6.97$ (d, J = 8.7 Hz, 2H), 3.86 (s, 3H) ppm; ${ }^{13} \mathrm{C}$ NMR $\left(\mathrm{CDCl}_{3}\right): \delta=159.3,139.2,132.5,128.8,128,127.9,125.9$, 114.3, 55.3 ppm; MS: m/z (\%) = $220\left(\mathrm{M}^{+}+2\right.$, 37.7), $218\left(\mathrm{M}^{+}\right.$, 88.7), 203 (66), 175 (62.3), 152 (47.2), 139 (56.6), 111 (24.5), 101 (30.2), 87 (49.1), 75 (67.9), 63 (79.2), 57 (100).

4-Methoxy-4'-nitrobiphenyl (3j, $\left.\mathrm{C}_{7} \mathrm{H}_{11} \mathrm{NO}_{3}\right)$

Yellow powder; m.p.: $105^{\circ} \mathrm{C}-106^{\circ} \mathrm{C} ;{ }^{1} \mathrm{H} \mathrm{NMR}\left(\mathrm{CDCl}_{3}\right): \delta=8.27(\mathrm{~d}, \mathrm{~J}=8.7 \mathrm{~Hz}, 2 \mathrm{H}), 7.70(\mathrm{~d}, \mathrm{~J}=8.7 \mathrm{~Hz}, 2 \mathrm{H})$, 
7.58 (d, J = 8.7 Hz, 2H), 7.04 (d, J = 8.7 Hz, 2H), 3.89 (s, 3H) ppm; ${ }^{13} \mathrm{C} \mathrm{NMR}\left(\mathrm{CDCl}_{3}\right): \delta=160.4,147.2,131.1$, 128.5, 127.0, 124.1, 114.6, 55.4 ppm; MS: m/z (\%) = 229 (M+1 100), 199 (25.4), 183 (13.9), 168 (23), 139 (49.8), 63 (23.2).

4-Acetylbiphenyl (3k, $\left.\mathrm{C}_{14} \mathrm{H}_{12} \mathrm{O}\right)$.

${ }^{1} \mathrm{H}$ NMR $\left(\mathrm{CDCl}_{3}\right): \delta=8.01-8.05$ (m, 2H), $7.70-7.60(\mathrm{~m}, 4 \mathrm{H}),, 7.50-7.38(\mathrm{~m}, 3 \mathrm{H}), 2.63(\mathrm{~s}, 3 \mathrm{H}) ;{ }^{13} \mathrm{C}$ NMR (CDCl3): $\delta=197.9,146.0,140.1,136.1,129.2,129.1,128.5,127.5,127.4,26.8$; MS: $196\left(\mathrm{M}^{+}\right), 181,152,76$, 43.

4,4'-Dimethoxybiphenyl (3l, $\left.\mathrm{C}_{14} \mathrm{H}_{14} \mathrm{O}_{2}\right)$

Colorless crystals; m.p.: $175^{\circ} \mathrm{C}-176^{\circ} \mathrm{C} ;{ }^{1} \mathrm{H}$ NMR $\left(\mathrm{CDCl}_{3}\right): \delta=7.51(\mathrm{~d}, \mathrm{~J}=8.7 \mathrm{~Hz}, 4 \mathrm{H}), 6.98(\mathrm{~d}, \mathrm{~J}=8.7 \mathrm{~Hz}$, 4H), 3.88 (s, 6H) ppm; ${ }^{13} \mathrm{C}$ NMR $\left(\mathrm{CDCl}_{3}\right): \delta=158.8$ 133.8, 127.6, 114.5, 55.7 ppm; MS: m/z (\%) = $214\left(\mathrm{M}^{+}\right.$, 93.4), 199 (100), 171 (36.8), 156 (25), 128 (48.7), 115 (17.1), 102 (28.9), 91 (39.5), 74 (32.9), 63 (47.4), 51 (38.2).

4,4'-Dichlorobiphenyl (3m, $\mathrm{C}_{12} \mathrm{H}_{8} \mathrm{C}_{12}$ )

white solid; m.p.: $150^{\circ} \mathrm{C} ;{ }^{1} \mathrm{H}$ NMR $\left(\mathrm{CDCl}_{3}\right): \delta=7.46(\mathrm{~d}, \mathrm{~J}=8 \mathrm{~Hz}, 4 \mathrm{H}), 7.39(\mathrm{~d}, \mathrm{~J}=7.6 \mathrm{~Hz}, 4 \mathrm{H}) \mathrm{ppm} ;{ }^{13} \mathrm{C}$ $\operatorname{NMR}\left(\mathrm{CDCl}_{3}\right): \delta=127.2,128.0,132.7,137.4 \mathrm{ppm}$.

4, 4'-Dimethylbiphenyl (3n, $\mathrm{C}_{14} \mathrm{H}_{14}$ )

White solid; m.p.: $124^{\circ} \mathrm{C}-125^{\circ} \mathrm{C} ;{ }^{1} \mathrm{H}$ NMR $\left(\mathrm{CDCl}_{3}\right): \delta=7.51(\mathrm{~d}, \mathrm{~J}=8.1 \mathrm{~Hz}, 4 \mathrm{H}), 7.26(\mathrm{~d}, \mathrm{~J}=8.1 \mathrm{~Hz}, 4 \mathrm{H})$, 2.42 (s, 6H) ppm; ${ }^{13} \mathrm{C}$ NMR $\left(\mathrm{CDCl}_{3}\right): \delta=136.8,129.7,138.5,127.0,21.3 \mathrm{ppm}$.

4,4'-Dicyanobiphenyl (3o, $\mathrm{C}_{14} \mathrm{H}_{8} \mathrm{~N}_{2}$ )

white solid; m.p.: $234^{\circ} \mathrm{C} ;{ }^{1} \mathrm{H}$ NMR $\left(\mathrm{CDCl}_{3}\right): \delta=7.75$ - 7.82 (m, $\left.4 \mathrm{H}\right), 7.68-7.74$ (m, $\left.4 \mathrm{H}\right) \mathrm{ppm} ;{ }^{13} \mathrm{C}$ NMR $\left(\mathrm{CDCl}_{3}\right): \delta=112.4,118.4,127.9,132.8,143.5 \mathrm{ppm}$.

4-Chlorobiphenyl (3p, $\mathrm{C}_{12} \mathrm{H}_{9} \mathrm{Cl}$ ) Viscous liquid; m.p.:77 ${ }^{\circ} \mathrm{C}-78^{\circ} \mathrm{C}:{ }^{1} \mathrm{H}$ NMR $\left(\mathrm{CDCl}_{3}\right): \delta=7.55(\mathrm{~m}, 4 \mathrm{H}), 7.41$ (m, 5H) ppm; ${ }^{13} \mathrm{C} \mathrm{NMR}\left(\mathrm{CDCl}_{3}\right): \delta=140.0135 .6,133.3,128.9,128.8,128.4,126.9,127.6 \mathrm{ppm}$; IR (KBr): $\bar{v}=$ $1420,1114,1061,892,803 \mathrm{~cm}^{-1}$.

\section{Conclusion}

The present research work has undertaken the study of the bi-activation of some coupling reactions by phase transfer catalysis (PTC) coupled with ultrasounds. The effect of phase transfer catalysis associated with ultrasound waves on the reactivity of certain organic reactions such as Suzuki and Hiyama was therefore also examined. The obtained results have demonstrated that Suzuki reactions are significantly favored in the presence of ultrasound in an aqueous environment. The use of Aliquat-336 plays an important role in the reduction of $\mathrm{Pd}(\mathrm{II})$ as well as in the stabilisation and solubilisation of $\mathrm{Pd}(0)$.

\section{Acknowledgements}

We greatly acknowledge financial support of the Ministry of Higher Education and Scientific Research of Tunisia.

\section{References}

[1] Meciarova, M., Toma, S. and Magdolen, P. (2003) Ultrasound Effect on the Aromatic Nucleophilic Substitution Reactions on Some Haloarenes. Ultrasonics Sonochemistry, 10, 265-270. http://dx.doi.org/10.1016/S1350-4177(02)00157-8

[2] Palimkar, S.S., More, V.S. and Srinivasan, K.V. (2008) Ultrasound Promoted Copper-, Ligand- and Amine-Free Synthesis of Benzo[b]furans/nitro Benzo[b]furans via Sonogashira Coupling-5-Endo-Dig-Cyclization. Ultrason Sonochem, 15, 853-862. http://dx.doi.org/10.1016/j.ultsonch.2007.10.006

[3] Hamdaoui, O., Naffrechoux, E., Tifouti, L. and Petrier, C. (2003) Effect of Ultrasound on Adsorption-Desorption of p-Chlorophenol on Granular Activated Carbón. Ultrason Sonochem, 10, 109-114. http://dx.doi.org/10.1016/S1350-4177(02)00137-2

[4] Saïd, K., Moussaoui, Y., Kammoun, M. and Ben Salem, R. (2011) Ultrasonic Activation of Heck Type Reactions in the Presence of Aliquat-336 Ultrason Sonochem, 18, 23-28. http://dx.doi.org/10.1016/j.ultsonch.2010.04.007

[5] Mhamdi, L., Saïd, K., Moussaoui, Y. and Ben Salem, R. (2013) Biactivation de la réaction de Sonogachira par la catalyse par transfert de phase et sous irradiation ultrasonique. Journal de la société chimique de Tunisie, 15, 149-162.

[6] Saïd, K., Kammoun, M., Moussaoui, Y. and Ben Salem, R. (2011) The Effect of Ultrasound on the Yields of Heck 
Reaction Using Pd-Catalyst in DMF/Wáter. Mediterranean Journal of Chemistry, 1, 13-18. http://dx.doi.org/10.13171/mjc.1.1.2011.18.05.12

[7] Mason, T.J., Lorimer, J.P. and Bates, D.M. (1992) Quantifying Sonochemistry-Casting Some Light on a "Black Art”. Ultrasonics, 30, 40-42. http://dx.doi.org/10.1016/0041-624X(92)90030-P

[8] Ambulgekar, G.V., Bhanage, B.M. and Samant, S.D. (2005) Low Temperature Recyclable Catalyst of Heck Reaction Using Ultrasound. Tetrahedron Letters, 46, 2483, 2484.

[9] Deshmukh, R.R., Rajagopal, R. and Srinivasan, K.V. (2001) Ultrasound Promoted C-C Bond Formation: Heck Reaction at Ambient Conditions in Room Temperature Ionic Liquids. Chemical Communications, 17, 1544-1545. http://dx.doi.org/10.1039/b104532f

[10] Zhang, J., Yang, F., Ren, G., Mak, T.C.W., Song, M. and Wu, Y. (2008) Ultrasonic Irradiation Accelerated Cyclopalladated Ferro Cenylimines Catalyzed Suzuki Reaction in Neat Water. Ultrasonics Sonochemistry, 15, 115-118. http://dx.doi.org/10.1016/j.ultsonch.2007.02.002

[11] Moussaoui, Y., Saïd, K. and Ben Salem, R. (2006) Anionic Activation of the Wittig Reaction Using a Solid-Liquid Phase Transfer: Examination of the Medium-, Temperature-, Base- and Phase-Transfer Catalyst Effects. Arkivoc, xii, $1-22$.

[12] Saïd, K., Moussaoui, Y. and Ben Salem, R. (2009) Heck Coupling Styrene With Aryl Halydes Catalyzed by Palladium Complexes in Biphasic Media. Journal de la Société Chimique de Tunisie, 11, 59-67.

[13] El-Sharkawy Ali, H. (2007) Cycloalkylation Reactions of Fatty Amines with $\alpha, \omega$-Dihaloalkanes: Role of Bis-Quaternary Ammonium Salts as Phase-Transfer Catalysts. Catalysis Communications, 8, 855-860. http://dx.doi.org/10.1016/j.catcom.2006.09.013

[14] Mhamdi, L., Bohli, H., Moussaoui, Y. and Ben Salem, R. (2011) Phase Transfer Catalysis of Henry and Darzens Reactions. International Journal of Organic Chemistry, 1, 119-124. http://dx.doi.org/10.4236/ijoc.2011.13018

[15] Slimi, H., Saïd, K., Moussaoui, Y. and Ben Salem, R. (2013) Phase Transfer Catalysis Improved Synthesis of 3,4Dihydropyrimidinones. International Journal of Organic Chemistry, 3, 96-100. http://dx.doi.org/10.4236/ijoc.2013.33a009

[16] Deshages, S, Liagre, M., Loupy, A., Luche, J. and Petit, A. (1999) Microwave Activation in Phase Transfer Catalysis. Tetrahedron, 55, 10851-10870. http://dx.doi.org/10.1016/S0040-4020(99)00601-8

[17] Borhade, S.R. and Waghmode, S.B. (2010) Studies on Phosphine Free Pd-Salem Complexes as Effective Catalysts for Aqueous Suzuki Reaction. Indian Journal of Chemistry, 49B, 565-572.

[18] Yuan, D., Chen, L., Yuan, L., Liao, S., Yang, M. and Zhang, Q. (2016) Superparamagnetic Polymer Composite Microspheres Supported Schiff Base Palladium Complex: An Efficient and Reusable Catalyst for the Suzuki Coupling Reactions. Chemical Engineering Journal, 287, 241-251. http://dx.doi.org/10.1016/j.cej.2015.10.081

[19] Ghorbani-Choghamarani, A. and Rabiei, H. (2016) Synthesis, Characterization, and Application of Palladium-Dithizone Immobili Zed on Magnetic Nanoparticles as an Efficient and Recoverable Catalyst for Suzuki Type Coupling Reactions. Tetrahedron Letters, 57, 159-162. http://dx.doi.org/10.1016/j.tetlet.2015.11.096

[20] Naghipour, A. and Fakhri, A. (2016) Heterogeneous $\mathrm{Fe}_{3} \mathrm{O}_{4} @$ Chitosan-Schiff Base Pd Nanocatalyst: Fabrication, Characterization and Application as Highly Efficient and Magnetically-Recoverable Catalyst for Suzuki-Miyaura and Heck-Mizoroki C-C Coupling Reactions. Catalysis Communications, 73, 39-45. http://dx.doi.org/10.1016/j.catcom.2015.10.002

[21] Miyaura, N., Yamada, K. and Suzuki, A. (1979) A New Stereospecific Cross-Coupling by the Palladium Catalyzed Reaction of 1-Alkenylboranes with 1-Alkenyl or 1-Alkynyl Halides. Tetrahedron Letters, 20, 3437-3440. http://dx.doi.org/10.1016/S0040-4039(01)95429-2

[22] Suzuki, A. (2005) Carbon-Carbon Bonding Made Easy. Chemical Communications, No. 38, 4759-4763. http://dx.doi.org/10.1039/b507375h

[23] Alonso, F., Beletskaya, I.P. and Yus, M. (2008) Non-Conventional Methodologies for Transition-Metal Catalysed Carbon-Carbon Coupling: A Critical Overview. Part 2: The Suzuki reaction. Tetrahedron, 64, 3047-30101. http://dx.doi.org/10.1016/j.tet.2007.12.036

[24] Paluru, D.K., Dey, S., Chaudhari, K.R., Khedkar, M.V. and Bhanage, B.M. (2014) Palladium(II) Chalcogenolate Complexes as Catalysts for C-C Cross-Coupling and Carbonylative Suzuki Coupling Reactions. Tetrahedron Letters, 55, 2953-2956. http://dx.doi.org/10.1016/j.tetlet.2014.03.101

[25] Zhang, H., Wang, C., Li, Z. and Wang, Z. (2015) Palladium-Catalyzed Enitrogenative Hiyama Cross-Coupling with Arylhydrazines under Air. Tetrahedron Letters, 56, 5371-5376. http://dx.doi.org/10.1016/j.tetlet.2015.06.095

[26] Rostamnia, S., Hossieni, H.G. and Doustkhah, E. (2015) Homoleptic Chelating N-Heterocyclic Carbene Complexes of Palladium Immobilized within the Pores of SBA-15/IL (NHC-Pd@SBA-15/IL) as Heterogeneous Catalyst for Hiyama 
Reaction. Journal of Organometallic Chemistry, 791, 18-23. http://dx.doi.org/10.1016/j.jorganchem.2015.05.019

[27] Denmark, S.E. and Regens, C.S. (2008) Palladium-Catalyzed Cross-Coupling Reactions of Organosilanols and Their Salts: Practical Alternatives to Boron- and Tin-Based Methods. Accounts of Chemical Research, 41, 1486-1499. http://dx.doi.org/10.1021/ar800037p

[28] Hiyama, T. (2002) How I Came across the Silicon-Based Cross-Coupling Reaction. Journal of Organometallic Chemistry, 653, 58-61. http://dx.doi.org/10.1016/S0022-328X(02)01157-9

[29] Ranu, B.C., Dey, R. and Chattopadhyay, K. (2008) A One-Pot Efficient and Fast Hiyama Coupling Using Palladium Nanoparticles in Water under Fluoride-Free Conditions. Tetrahedron Letters, 49, 3430-3432. http://dx.doi.org/10.1016/j.tetlet.2008.03.121

[30] Blaszczyk, I. and Trzeciak, A.M. (2010) Suzuki-Miyaura and Hiyama Reactions Catalyzed by Orthopalladated Triarylphosphite Complexes. Tetrahedron, 66, 9502-9507. http://dx.doi.org/10.1016/j.tet.2010.10.021

[31] McNamara, C.A., Dixon, M.J. and Bradley, M. (2002) Reccoverable Catalysts and Reagents Using Recyclable Polystyrene-Based Supports. Chemical Reviews, 102, 3275-3300. http://dx.doi.org/10.1021/cr0103571

[32] Lu, J. and Toy, P.H. (2009) Organic Polymer Supports for Synthesis and for Reagent and Catalyst Immobilization. Chemical Reviews, 109, 815-838. http://dx.doi.org/10.1021/cr8004444

[33] Lamblin, M., Nassar-Hardy, L., Hierso, J.-C., Fouquet, E. and Felpin, F.-X. (2010) Recyclable Heterogeneous Palladium Catalysts in Pure Water: Sustainable Developments in Suzuki, Heck, Sonogashira and Tsuji-Trost Reactions. Advanced Synthesis \& Catalysis, 352, 33-79. http://dx.doi.org/10.1002/adsc.200900765

[34] Dhondge, A.P., Shaikh, A.C. and Chen, C. (2012) Apineno-Salen Type Catalyst for the Enantioselective NozakiHiyama-Kishi Reaction. Tetrahedron: Asymmetry, 23, 723-733. http://dx.doi.org/10.1016/j.tetasy.2012.05.012

[35] Shah, D. and Kaur, H. (2012) Macroporous Resin Impregnated Palladium Nanoparticles: Catalyst for a MicrowaveAssisted Green Hiyama Reaction. Journal of Molecular Catalysis A: Chemical, 359, 69-73. http://dx.doi.org/10.1016/j.molcata.2012.03.022

[36] Barder, T.E., Walker, S.D., Martinelli, J.R. and Buchwald, S.L. (2005) Catalysts for Suzuki-Miyaura Coupling Processes: Scope and Studies of the Effect of Ligand Structure. Journal of the American Chemical Society, 127, 46854696. http://dx.doi.org/10.1021/ja042491j

[37] Sore, H.F., Galloway, W.R.J.D. and Spring, D.R. (2012) Palladium-Catalysed Cross-Coupling of Organosilicon Reagents. Chemical Society Reviews, 41, 1845-1866. http://dx.doi.org/10.1039/C1CS15181A

[38] Yang, G.R., Bae, G., Choe, J., Lee, S. and Song, K.H. (2010) Silica-Supported Palladium-Catalyzed Hiyama CrossCoupling Reactions Using Continuous Flow System. Bulletin of the Korean Chemical Society, 31, 250-252. http://dx.doi.org/10.5012/bkcs.2010.31.01.250

[39] Hatanaka, Y. and Hiyama, T. (1988) Cross-Coupling of Organosilanes with Organic Halides Mediated by a Palladium Catalyst and Tris(Diethylamino)Sulfonium Difluorotrimethylsilicate. The Journal of Organic Chemistry, 53, 918-920. http://dx.doi.org/10.1021/jo00239a056 